\title{
Biodegradation
}

How UV photolysis accelerates the biodegradation and mineralization of sulfadiazine
(SD)

--Manuscript Draft--

\begin{tabular}{|c|c|}
\hline \multicolumn{2}{|l|}{ Manuscript Number: } \\
\hline Full Title: & $\begin{array}{l}\text { How UV photolysis accelerates the biodegradation and mineralization of sulfadiazine } \\
\text { (SD) }\end{array}$ \\
\hline Article Type: & Original research article \\
\hline Keywords: & Sulfadiazine (SD), UV irradiation, biodegradation, photolysis products, kinetics \\
\hline Corresponding Author: & $\begin{array}{l}\text { Yong Ming Zhang, Ph.D } \\
\text { Shanghai Normal University } \\
\text { Shanghai, CHINA }\end{array}$ \\
\hline \multicolumn{2}{|l|}{$\begin{array}{l}\text { Corresponding Author Secondary } \\
\text { Information: }\end{array}$} \\
\hline Corresponding Author's Institution: & Shanghai Normal University \\
\hline \multicolumn{2}{|l|}{$\begin{array}{l}\text { Corresponding Author's Secondary } \\
\text { Institution: }\end{array}$} \\
\hline First Author: & Shihui Pan \\
\hline \multicolumn{2}{|l|}{ First Author Secondary Information: } \\
\hline \multirow[t]{7}{*}{ Order of Authors: } & Shihui Pan \\
\hline & Ning Yan, PhD \\
\hline & Xinyue Liu \\
\hline & Wenbing Wang \\
\hline & Yong Ming Zhang, Ph.D \\
\hline & Rui Liu, PhD \\
\hline & Bruce E Rittmann, PhD \\
\hline \multicolumn{2}{|c|}{ Order of Authors Secondary Information: } \\
\hline Abstract: & $\begin{array}{l}\text { Sulfadiazine (SD), one of broad-spectrum antibiotics, exhibits limited biodegradation in } \\
\text { wastewater treatment due to its chemical structure, which requires initial mono- } \\
\text { oxygenation reactions to initiate its biodegradation. Intimately coupling UV photolysis } \\
\text { with biodegradation, realized with the internal loop photobiodegradation reactor } \\
\text { (ILPBR), accelerated SD biodegradation and mineralization by } 40 \% \text { and } 71 \% \text {, } \\
\text { respectively. The main organic products from photolysis were 2-aminopyrimidine (2- } \\
\text { AP), p-aminobenzenesulfonic acid (ABS), and aniline (An), and an SD-photolyisis } \\
\text { pathway could be identified using C, N, and S balances. Adding An or ABS (but not 2- } \\
\text { AP) into the SD solution during biodegradation experiments (no UV photolysis) gave } \\
\text { SD removal and mineralization rates similar to intimately coupled photolysis and } \\
\text { biodegradation. An SD biodegradation pathway, based on a diverse set of the } \\
\text { experimental results, explains how the mineralization of ABS provided internal electron } \\
\text { carriers that accelerated the initial mono-oxygenation reactions of SD biodegradation. } \\
\text { Thus, multiple lines of evidence support that the mechanism by which intimately } \\
\text { coupled photolysis and biodegradation accelerated SD removal and mineralization was } \\
\text { through producing co-substrates whose oxidation produced electron equivalents that } \\
\text { stimulated the initial mono-oxygenation reactions for SD biodegradation. }\end{array}$ \\
\hline \multirow[t]{2}{*}{ Suggested Reviewers: } & $\begin{array}{l}\text { Seongjun Park, PhD } \\
\text { Samsung Construction and Trading, Seoul, } \\
\text { seongjun93.park@samsung.com } \\
\text { Dr. Park is an expert on biodegradation of recalcitrant organic compound }\end{array}$ \\
\hline & Elizabeth Dahlen, PhD \\
\hline
\end{tabular}


SLAC

eliz.dahlen@gmail.com

Dr. Dahlen is good at the mechanism of compund biodegradation

Michael D Marsolek, PhD

Seattle University, Seattle, WA 98122

marsolem@seattleu.edu

Dr. Marsolek is good at intimately coupled photocatalysis with biodegradation for organic compounds.

Maria Papadaki, PhD

University of loannina, Greece

mpapadak@cc.uoi.gr

Jian-Jiang Zhong, PhD

School of Life Science, Shanghai Jiaotong University

jjzhong@sjtu.edu.cn 


\section{How UV photolysis accelerates the biodegradation and mineralization of sulfadiazine (SD)}

Shihui Pan, Ning Yan, Xinyue Liu, Wenbing Wang, Yongming Zhang( $\left.{ }^{(}\right)$, Rui Liu, Bruce E.

Rittmann

Shihui Pan, Ning Yan, Xinyue Liu, Yongming Zhang

Department of Environmental Engineering, College of Life and Environmental Science, Shanghai

Normal University, Shanghai, 200234, P. R. China

Email: zhym@shnu.edu.cn

Telephone: +862164321071

Fax: +862164321071

Rui LIU

Zhejiang Provincial Key Laboratory of Water Science and Technology, Department of

Environmental Technology and Ecology, Yangtze Delta Region Institute of Tsinghua University, Zhejiang, Jiaxing 314006, P. R. China

Bruce E. RITTMANN

Swette Center for Environmental Biotechnology, Biodesign Institute, Arizona State University, Tempe, AZ85287-5701, USA 


\begin{abstract}
:
Sulfadiazine (SD), one of broad-spectrum antibiotics, exhibits limited biodegradation in wastewater treatment due to its chemical structure, which requires initial mono-oxygenation reactions to initiate its biodegradation. Intimately coupling UV photolysis with biodegradation, realized with the internal loop photobiodegradation reactor (ILPBR), accelerated SD biodegradation and mineralization by $40 \%$ and $71 \%$, respectively. The main organic products from photolysis were 2-aminopyrimidine (2-AP), p-aminobenzenesulfonic acid (ABS), and aniline (An), and an SD-photolyisis pathway could be identified using C, N, and S balances. Adding An or ABS (but not 2-AP) into the SD solution during biodegradation experiments (no UV photolysis) gave SD removal and mineralization rates similar to intimately coupled photolysis and biodegradation. An SD biodegradation pathway, based on a diverse set of the experimental results, explains how the mineralization of ABS provided internal electron carriers that accelerated the initial mono-oxygenation reactions of SD biodegradation. Thus, multiple lines of evidence support that the mechanism by which intimately coupled photolysis and biodegradation accelerated SD removal and mineralization was through producing co-substrates whose oxidation produced electron equivalents that stimulated the initial mono-oxygenation reactions for SD biodegradation.
\end{abstract}

Keywords: Sulfadiazine (SD), UV irradiation, biodegradation, photolysis products, kinetics 


\section{Introduction}

Sulfonamides (SAs) are broad-spectrum antibiotics widely used for prevention and treatment of animal diseases and promotion of livestock growth (Zhao et al., 2010; Liu and Wong, 2013). SAs are present in wastewaters involved with livestock production (Žegura et al., 2009), and this poses a health risk to human being when the SAs enter supplies of potable water (Kim and Tanaka, 2009; Periša $\mathrm{M}$ et al., 2013). Among the $\mathrm{SAs}$, sulfadiazine ( $\mathrm{SD}, \mathrm{C}_{10} \mathrm{H}_{10} \mathrm{~N}_{4} \mathrm{O}_{2} \mathrm{~S}$ ) is an important representative.

Many physical, chemical, and biological methods may be employed to reduce or remove SAs from wastewaters (Garcia et al., 2012). Among them, advanced oxidation processes (AOPs) show promise for SD degradation: e.g., ultrasound + hydrogen peroxide (Mohajerani et al., 2012), Fenton's reaction (Neafsey et al., 2009), ozonation (Zhou et al., 2011), $\mathrm{TiO}_{2}$ photocatalytic oxidation (Baran et al., 2009), and UV photolysis (Yan et al., 2012). AOPs alone are not practical to mineralize $\mathrm{SD}$, but they can modify the SD structure in ways that make it more readily removed by another process, such as biodegradation. Therefore, a good strategy is to couple an AOP with biodegradation for complete degradation of SAs. The AOP produces partial-breakdown products that accelerate the biodegradation and mineralization by being more readily biodegradable than the original recalcitrant compound (Zhang et al., 2012a), having less toxicity (Zhang et al., 2012b), or being oxidized to produce intracellular electron carriers that accelerate initial reactions (such as mono-oxygenations) for the biodegradation of the original compound (Zhang et al., 2014). Thus, coupling an AOP to biodegradation can increase the removal rate of the original compound by its direct action on the molecule and by its indirect effects. 
A promising means to couple an AOP with biodegradation is called intimate coupling, in which the AOP produces transformation products that are rapidly consumed by bacteria present in the same reactor (Marsolek et al., 2008; Li et al., 2012; Zhang et al., 2014). Intimate coupling overcomes problems that often plague a sequentially coupled system: Too much photolysis increases costs and can generate products to that are inhibitory or recalcitrant. Thus, intimate coupling allows intermediates to be biodegraded as soon they are formed.

Here, we focus on the benefits of intimately coupling UV photolysis with biodegradation for SD. We hypothesize that UV photolysis generates a series of biodegradable intermediates, and bacterial oxidation of the intermediates produces intracellular electron carriers for initial mono-oxygenation reactions needed to biodegrade SD (Sukul et al., 2008; Lafaille et al., 2014). Similar accelerations have been seen for biodegradation of 2,4-dichlorophenol (Dahlen and Rittmann, 2000), toluene and p-xylene (Yu et al., 2001), and pyridine (Zhang et al., 2014). Having a more complex structure, SD will release more and diverse photolysis products, and their ability to be oxidized to supply intracellular electron carriers is unknown.

In this work, we used an internal loop photolytic biofilm reactor (ILPBR) (Zhang et al. 2012b) to realize intimate coupling of UV photolysis with biodegradation for SD. We document that intimate coupling gave faster degradation and mineralization kinetics than photolysis alone or biodegradation alone. Just as importantly, we elaborate the mechanism by which intimately coupled UV photolysis accelerates SD biodegradation. 


\section{Materials and methods}

\subsection{Chemicals}

All chemicals were purchased through Sinopharm Chemical Reagent Co., Ltd in Shanghai, China. SD and p-aminobenzenesulfonic acid were from Sigma Co. Ltd. (USA); acetonitrile from Tedia (USA); methanol from Anaqua Chemicals Supply Co. Ltd. (USA); and 2-aminopyrimidine, aniline, acetic acid, and all inorganic salts from Sinopharm Chemical Reagent Co., Ltd in Shanghai (China).

\subsection{Inorganic salt, trace-element, and buffer stock solutions}

The inorganic salt solution was prepared by diluting into $250 \mathrm{~mL}$ of deionized water $4.775 \mathrm{~g}$ $\mathrm{NH}_{4} \mathrm{Cl}$ and $1.097 \mathrm{~g} \mathrm{KH}_{2} \mathrm{PO}_{4}$ to give a solution with $5 \mathrm{~g} \mathrm{~N} / \mathrm{L}$ and $1 \mathrm{~g} \mathrm{P} / \mathrm{L}$. The trace-element solution was $(\mathrm{g} / \mathrm{L}): \mathrm{FeCl}_{2} \bullet 4 \mathrm{H}_{2} \mathrm{O} \quad 1.5, \mathrm{NiCl}_{2} \bullet 6 \mathrm{H}_{2} \mathrm{O} 0.024, \mathrm{CoCl}_{2} \bullet 6 \mathrm{H}_{2} \mathrm{O} \quad 0.19, \mathrm{CuCl}_{2} \bullet 2 \mathrm{H}_{2} \mathrm{O} 0.002$, $\mathrm{MnSO}_{4} \cdot 7 \mathrm{H}_{2} \mathrm{O} 0.1, \mathrm{Na}_{2} \mathrm{MoO}_{4} \cdot 2 \mathrm{H}_{2} \mathrm{O} 0.024, \mathrm{ZnCl}_{2}$ 0.07, and $\mathrm{H}_{3} \mathrm{BO}_{3}$ 0.006. The buffer solution was (g/L): $\quad \mathrm{KH}_{2} \mathrm{PO}_{4} 8.5, \mathrm{~K}_{2} \mathrm{HPO}_{4} 21.75, \mathrm{Na}_{2} \mathrm{HPO}_{4} \bullet 7 \mathrm{H}_{2} \mathrm{O} 33.4$, and $\mathrm{NH}_{4} \mathrm{Cl}$ 1.7. These stock solutions were stored in a refrigerator at $4^{\circ} \mathrm{C}$.

\subsection{Preparation of SD solutions}

$1 \mathrm{~g} \mathrm{SD}$ was diluted in $800 \mathrm{~mL}$ deionized water, and the $\mathrm{pH}$ was adjusted to 10 with $0.1 \mathrm{M}$ $\mathrm{NaOH}$. Once the SD was fully dissolved, more deionized water was added to give $1000 \mathrm{~mL}$, which gave an SD stock solution of $1000 \mathrm{mg} / \mathrm{L}$. It was stored in a refrigerator at $4^{\circ} \mathrm{C}$. During an experiment, the stock solution was diluted with deionized water to give an SD concentration in the 
range of 5 to $100 \mathrm{mg} / \mathrm{L}$. All solutions were then adjusted to $\mathrm{pH} 7$ by addition of the buffer solution, and $1 \mathrm{~mL}$ each of the inorganic salt and trace element solutions were added for each $1 \mathrm{~L}$ of solution used for biodegradation experiments.

\subsection{Internal loop photo-biodegradation reactor (ILPBR)}

An internal loop photolytic biofilm reactor (ILPBR) was made of quartz glass with a 45-mL working volume (Zhang et al., 2012b). A glass baffle was installed in the center of the ILPBR to create photolysis and biodegradation zones within one reactor. The biofilm carriers in the biodegradation zone were hydroformylated fibers produced by an aldehyde reaction; they were soft plastic fibers having a rough outer surface ideal for biofilm attachment. An air-lift pump circulated water between the photolysis zone and the biodegradation zone at a rate of $80 \mathrm{~mL} / \mathrm{min}$. When only UV photolysis was carried out, the biofilm carriers were was not present, and the UV light was on. When only biodegradation was carried out, the biofilm carriers were installed in the ILPBR, but the UV light was off. Intimately coupled UV photolysis and biodegradation had biofilm carriers installed and the UV light on.

\subsection{Acclimation of SD-degrading bacteria and preparation of biofilm}

Activated sludge was obtained from the underflow of a secondary clarifier at the Longhua municipal wastewater treatment plant in Shanghai. For acclimation under aerobic conditions, 100 mL sludge was added into a 500-mL graduated cylinder; fresh medium with $300 \mathrm{mg} / \mathrm{L}$ of COD was replaced every day for seven days, and the temperature was $25-30^{\circ} \mathrm{C}$. The medium was prepared 
with glucose, ammonium chloride, and potassium dihydrogen phosphate based on the mass ratio of COD:N:P = 100:5:1, and it also included $1 \mathrm{~mL}$ each of inorganic salt, buffer, and trace element solutions.

For each of the next 14 days, we partially replaced glucose with SD in the medium. In 5 steps, we decreased the glucose concentration from $300 \mathrm{mg} / \mathrm{L}$ to $260 \mathrm{mg} / \mathrm{L}$, while increasing the SD concentration from zero to $20 \mathrm{mg} / \mathrm{L}$ to keep the same COD concentration $(300 \mathrm{mg} / \mathrm{L})$. During the acclimation, we replaced the medium every day, and the acclimation strategy was continued until the SD removal percentage exceeded $98 \%$ in 3 days.

To harvest SD-degrading bacteria, the acclimated sludge was settled, the supernatant was filtered through coarse filter paper (pore size $80 \sim 120 \mu \mathrm{m}$ ), and the filtrate contained the SD-degrading bacteria. The filtrate was stored in a refrigerator at $4^{\circ} \mathrm{C}$ until use, which occurred within 5 days.

To obtain SD-degrading biofilm, fibers was immerged the acclimated sludge for another 5 days. The medium containing $20 \mathrm{mg} / \mathrm{L} \mathrm{SD}$ and $260 \mathrm{mg} / \mathrm{L}$ glucose and was replaced every day until visible biofilm accumulated on the fiber.

\subsection{Experiments in the ILPBR}

Before SD degradation, control experiments were carried out in the ILPBR with heat-inactivated biofilm (Yan et al., 2012) and without UV illumination to investigate any adsorption of SD to the biofilm or the carrier. Then, three protocols -- photolysis alone (P), biodegradation alone (B), and simultaneous photolysis and biodegradation $(\mathrm{P} \& \mathrm{~B})$-- were used for 
evaluating degradation of SD in batch experiments at $25^{\circ} \mathrm{C}$. During each experiment, samples were taken at time intervals to measure SD concentrations. P experiments were carried out with the UV light turned on, no biofilm present in the biodegradation zone, and the solution circulated between the photolysis zone and the biodegradation zone by airlift pumping. The UV wavelength was $254 \mathrm{~nm}$, the power was $24 \mathrm{~W}$, the light intensity was about $1.0 \mathrm{~mW} / \mathrm{cm}^{2}$, and the distance between the UV light and reactor was $10 \mathrm{~cm}$. For the B experiments, biofilm-coated fibers were installed in the reactor, the UV light was turned off, and liquid circulation was driven by airlift aeration as in the $\mathrm{P}$ experiments. For the $\mathrm{P} \& \mathrm{~B}$ experiments, biofilm was installed in the ILPBR, and the UV light was on at the same time.

We also conducted a series of experiments in which we evaluated the effects of UV-hydrolysis products on biodegradation of SD. All of the experiments were carried out with 16 $\mathrm{mg} / \mathrm{L} \mathrm{SD}$ and the B protocol, but had different additions of photolysis products. In one experiment, the products were generated by exposing a $20-\mathrm{mg} / \mathrm{L} \mathrm{SD}$ solution to UV illumination for 0.5 hour, which decreased the $\mathrm{SD}$ concentration to $16 \mathrm{mg} / \mathrm{L}$; this medium was then used for a B experiment. We also conducted experiments in which one or all three of the main photolysis products (ABS, An, and 2-AP) were added at concentrations equal to what was formed in a P experiment. The starting materials and nomenclature for each experiment are given in Table 1.

\subsection{Fate of $\mathbf{N}$ and $\mathrm{S}$ in $\mathrm{SD}$}

In order to elaborate the SD-biodegradation pathway, we carried out special B and P\&B experiments having an initial SD concentration of $10 \mathrm{mg} / \mathrm{L}$. We measured $\mathrm{NH}_{4}{ }^{+}$and $\mathrm{SO}_{4}{ }^{2-}$ 
concentrations in parallel to the loss of SD. This allowed us to relate the release of $\mathrm{N}$ and $\mathrm{S}$ to the loss of SD. For these experiments, we allowed the SD solutions to mix in the ILPBR for 2 min before taking the first sample. We designate this first sample as time $=0$.

\subsection{Analytical methods}

SD and 2-AP were measured by a high performance liquid chromatograph (model: Agilent 1100, USA) equipped with a diode array detector with wavelength of $269 \mathrm{~nm}$ and ZORBAX SB-C18 column $(5 \mu \mathrm{m}, 4.6 \times 150 \mathrm{~mm})$. The mobile phase was a mixture of acetonitrile-water solution $(25: 75, \mathrm{v} / \mathrm{v})$, its $\mathrm{pH}$ was adjusted with acetic acid to 4 , and the flow rate was $1 \mathrm{~mL} / \mathrm{min}$. The column temperature was kept at $35^{\circ} \mathrm{C}$, a $20-\mu \mathrm{L}$ sample was injected, and the detection limit was $5 \mathrm{ng} / \mathrm{mL}$ (Zhou et al., 2011). An and ABS were measured with the same ZORBAX SB-C18 column, but the wavelength was $205 \mathrm{~nm}$, and the mobile phase was $0.1 \mathrm{M}$ ammonium dihydrogen phosphate solution with $1 \mathrm{~mL} / \mathrm{min}$ flow rate. The column temperature was kept at $25^{\circ} \mathrm{C}, 20 \mu \mathrm{L}$ was injected, and the detection limit was $5 \mu \mathrm{g} / \mathrm{L}$ (Wang et al., 2002).

Inorganic ions were measured with ion chromatography (model: DIONEX ICS-5000, USA). For the ammonium cation, the separation column was IonPac CG12A $(50 \times 4 \mathrm{~mm}, \mathrm{~S} / \mathrm{N} 022328)$, and the mobile phase (eluent) was $20 \mathrm{mM}$ (methanesulfonic acid) MSA at $1.0 \mathrm{~mL} / \mathrm{min}$. For sulfate, nitrate, and nitrite anions, the separation column was IonPac AG18 (50×4 mm), and the eluent was mixed solution of $\mathrm{Na}_{2} \mathrm{CO}_{3}(4.5 \mathrm{mM})$ and $\mathrm{NaHCO}_{3}(0.8 \mathrm{mM})$ at a flow rate of $1.0 \mathrm{~mL} / \mathrm{min}$.

The TOC concentration was analyzed by using a TOC analyzer (Model: SHIMADZU, TOC-VCSN). The UV-light intensity was measured by an illuminometer (model BG-2254, China). Optical density (OD) was measured by spectrophotometer (model UV-2550, SHIMADZU, 
Japan) with a wavelength of $600 \mathrm{~nm}$. The biomass concentration as dry weight was calculated based on a calibration curve of OD versus dry weight (von Stosch et al. 2012; Wan et al. 2012). 


\section{Results and discussions}

\subsection{ILPBR for SD photo-biodegradation and mineralization}

Figure 1 compares the results for SD removal with protocols $\mathrm{P}, \mathrm{B}$, and $\mathrm{P} \& \mathrm{~B}$ in the ILPBR over a 4-hour period with an initial SD concentration of $22 \mathrm{mg} / \mathrm{L}$. The control results (no biodegradation or photolysis) also are shown and indicate minimal loss after 10 minutes. The most important finding in Figure 1 is that SD removal by $\mathrm{P} \& \mathrm{~B}$ was faster than that by $\mathrm{B}$ or by $\mathrm{P}$. In order to compare the kinetics for each protocol directly, we approximated the SD-removal kinetics as zero order after the first $10 \mathrm{~min}$. The rates are $5.0 \mathrm{mg} / \mathrm{L}-\mathrm{h}$ by $\mathrm{P} \& \mathrm{~B}, 4.5 \mathrm{mg} / \mathrm{L}-\mathrm{h}$ by $\mathrm{P}$, and $3.7 \mathrm{mg} / \mathrm{L}-\mathrm{h}$ by $\mathrm{B}$; thus, P\&B was $40 \%$ faster than B.

The corresponding TOC removal percentages, reflecting SD mineralization at the end of the 4-h B and P\&B experiments, are shown in Figure 2. Protocol P did not give any TOC removal and is not shown. P\&B gave $60 \%$ TOC removal, which is higher by $71 \%$ than for protocol $\mathrm{B}$, which had 35\% TOC removal. Thus, intimately coupled photolysis and biodegradation accelerated SD mineralization even more than was its impact on biodegradation of SD.

\subsection{SD photolysis products and pathway}

To investigate SD intermediates from UV photolysis, we illuminated a 20-mg/L SD solution for a 4-h P experiment. Figure 3 shows the photolysis products as SD declined from $20 \mathrm{mg} / \mathrm{L}$ to $1.1 \mathrm{mg} / \mathrm{L}$. The dominant organic products (top panel) were 2-AP, ABS, and An. Sulfate and ammonia were released is parallel (bottom panel). As before, TOC removal was negligible and is not shown. 
Following the pathway patterns observed previously for SD by Wang et al. (2010) and the mass-balance strategy of Zhang et al. (2013), we developed the SD-photolysis pathway shown in Figure 4. The $\mathrm{C}, \mathrm{N}$, and $\mathrm{S}$ balances that underlie the pathway are summarized in Table 2. The mass balance errors are $<1 \%$ for all elements in Table 2. ABS $\left(\mathrm{C}_{6} \mathrm{H}_{7} \mathrm{NO}_{3} \mathrm{~S}\right)$ and 2- $\mathrm{AP}\left(\mathrm{C}_{4} \mathrm{H}_{5} \mathrm{~N}_{3}\right)$ are produced by hydrolysis reaction $\mathrm{A} ; \mathrm{An}\left(\mathrm{C}_{6} \mathrm{H}_{7} \mathrm{~N}\right)$ and $\mathrm{SO}_{4}{ }^{2-}$ are produced by another hydrolysis reaction B; 2-hydroxyhex-2,4-diendioic acid $\left(\mathrm{C}_{6} \mathrm{H}_{6} \mathrm{O}_{5}\right)$ and $\mathrm{NH}_{3}$ are produced by set of oxidations in reaction $\mathrm{C}$; and formic acid $\left(\mathrm{CH}_{2} \mathrm{O}_{2}\right)$ and $\mathrm{NH}_{3}$ are produced by oxidations and hydrolysis in reaction D. Significant are that ammonia is released from reactions $\mathrm{C}$ and $\mathrm{D}$ and that releases of aniline and sulfate require reaction $\mathrm{B}$, the transformation of $\mathrm{ABS}$.

\subsection{Accelerating SD biodegradation by means of co-substrates}

Based on the experimental results above, we hypothesized that one cause for the increase in SD removal and mineralization rates is that microbial oxidation of SD photolysis products generates electron equivalents that can be used as co-reactants for initial mono-oxygenation reactions; this is a type of co-substrate effect (Dahlen and Rittmann, 2000; Yu et al., 2001; Zhang et al., 2014). Thus, we performed B experiments with different combinations of the main photolysis products, as shown in Table 1.

The experimental results are shown in Figure 5, and zero-order-loss rates (mg SD/L-h), obtained by linear regression for results after $10 \mathrm{~min}$, are indicated by the slopes of the dashed lines, which match the experimental data well. The results in the top panel of Figure 5 show that removal of $\mathrm{SD}$ in the synthetic $\mathrm{SD}$ solution with all photolysis products $(\mathrm{SD}+\mathrm{An}+2-\mathrm{AP}+\mathrm{ABS})$ was 
almost the same as with the products produced by photolysis directly $(\operatorname{SD}(\mathrm{P}))$, and both were about $50 \%$ faster than with no photolysis products $(\mathrm{SD}(\mathrm{O}))$. The bottom panel of Figure 5 indicates that adding only 2-AP did not accelerate SD removal, but SD+An and SD+ABS gave accelerations about as strong as $\mathrm{SD}(\mathrm{P})$. These trend supports that microbial oxidation of An and ABS (but not 2-AP) provided reduced electron carriers needed as co-substrates for mono-oxygenation reactions used to initiate SD catabolism.

\subsection{SD biodegradation pathway}

We tracked the fate of $\mathrm{N}$ and $\mathrm{S}$ equivalents, together with SD biodegradation, in $\mathrm{B}$ and $\mathrm{P} \& \mathrm{~B}$ experiments having an initial SD concentration of $10 \mathrm{mg} / \mathrm{L}$. The results, shown in Figure 6, show that SD was degraded much faster in the P\&B experiment, as expected. The most important finding is that $\mathrm{N}$ and $\mathrm{S}$ releases were nearly equal to the $\mathrm{N}$ and $\mathrm{S}$ releases predicted from full mineralization of SD. We did not measure the TOC in these experiments, but Figure 2 reports that the TOC removal was $60 \%$ for $100 \%$ removal of SD in its $\mathrm{P} \& \mathrm{~B}$ experiment. If that pattern held true for the experiments of Figure 6, then the biodegradation pathway proceeded far enough that $\mathrm{N}$ and $\mathrm{S}$ no longer remained in any organic intermediates, even though not all of the $\mathrm{C}$ was oxidized to $\mathrm{CO}_{2}$.

Based on our results (Figures 1, 2, 5, and 6) and information from the literature, we propose the SD-biodegradation pathway in Figure 7. The first and second steps (A and B) of SD biodegradation are mono-oxygenations that form dihydroxyl sulfadiazine. They require molecular oxygen $\left(\mathrm{O}_{2}\right)$ and an intracellular electron donor (represented as $2 \mathrm{H}$ ). Step $\mathrm{C}$ is hydrolysis of 
dihydroxyl sulfadiazine, which produces p-aminobenzenesulfonic acid (ABS) and 2-amino-4,6-dihydropyrimidine (Wang et al., 2010). The ABS is further hydrolyzed to generate aniline and sulfate (step D) (Takeo et al., 1998). Aniline mineralization is initiated by means of a mono-oxygenation reaction (step E) (Takeo et al., 1998; Baran et al., 2009b; Sukul et al., 2008; Wang et al., 2010; Neafsey et al., 2009) that requires $\mathrm{O}_{2}$ and $2 \mathrm{H}$ and that inserts an $-\mathrm{OH}$ group into the ring ( $\mathrm{Li}$ et al., 2003) to form aminophenol $\left(\mathrm{C}_{6} \mathrm{H}_{7} \mathrm{NO}\right)$. This is followed by a hydrolytic substitution (step F) that replaces the amino group with hydroxyl group to form catechol $\left(\mathrm{C}_{6} \mathrm{H}_{4} \mathrm{O}_{2}\right)$ while generating ammonia $\left(\mathrm{NH}_{3}\right)$ simultaneously. Step $\mathrm{G}$ is a set of one mono-oxygenation reaction and two hydroxylation reactions that give 2-hydrohexa-2,4-diendioic acid $\left(\mathrm{HDA}, \mathrm{C}_{6} \mathrm{H}_{6} \mathrm{O}_{5}\right)$. Step $\mathrm{H}$ begins mineralization of $\mathrm{HAD}$ to form $\mathrm{CO}_{2}$ and $\mathrm{H}_{2} \mathrm{O}$, and it releases 20 electron equivalents via a series of hydroxylation and dehydrogenation reactions. Step I represents a set of hydration reactions that decompose 2-amino-4,6-dihydropyrimidine into formic acid and $\mathrm{NH}_{3}$. The formic acid is further mineralized to $\mathrm{CO}_{2}$ and $\mathrm{H}_{2} \mathrm{O}$ by a set of hydroxylation and dehydrogenation reactions $(\operatorname{step} \mathrm{J})$. 
Figure 7 directly tracks the electron and $\mathrm{C}$ equivalents in all the organic intermediates, and it shows the release of $\mathrm{N}$ and $\mathrm{S}$ as $\mathrm{NH}_{3}$ and $\mathrm{SO}_{4}{ }^{2-}$, respectively. $\mathrm{SD}$ contains $40 \mathrm{e}^{-}$equivalents, 10 equivalents of $\mathrm{C}, 4$ equivalents of $\mathrm{N}, 1$ equivalent of $\mathrm{S}$.

Looking first at electron equivalents in carbon, Steps A and B are mono-oxygenation reactions that require $2 \mathrm{e}^{-}$equivalents each, shown as $2 \mathrm{H}$. From step $\mathrm{C}$ to step $\mathrm{H}$, transformation of $\mathrm{ABS}$ requires $4 \mathrm{H}$ for the mono-oxygenations in Steps $\mathrm{E}$ and $\mathrm{G}$, but then generates $24 \mathrm{H}$ in steps $\mathrm{G}$ and $\mathrm{H}$. Therefore, the net yield of electron equivalents from full mineralization of ABS is $+20 \mathrm{H}$. However, the pathway must proceed past step $\mathrm{G}$ to gain the net yield of $\mathrm{e}^{-}$equivalents, because the net yield is zero up through step G. Thus, step H must occur in order that ABS transformation generate excess $\mathrm{H}$ that can accelerate the initial mono-oxygenation reactions. Mineralization of 2-amino-4,6-dihydroxypyrimidine (Steps I and $\mathrm{J}$ ) has a net yield of $+8 \mathrm{H}$, but it requires getting past step I.

Mineralization of the $\mathrm{C}$ in $\mathrm{SD}$ requires that steps $\mathrm{H}$ and $\mathrm{J}$ occur, since no $\mathrm{CO}_{2}$ is released in prior steps. $60 \%$ of the C originally present in SD is released in the ABS pathway, steps D through $\mathrm{H}$; the remaining $40 \%$ are routed through Steps I and J. The TOC results of Figure 2 (60\% loss of TOC) suggest that step $\mathrm{H}$ occurred, but step $\mathrm{J}$ did not occur. This means that the remaining $\mathrm{C}$ accumulated as formic acid.

Turing now to the fates of $\mathrm{N}$ and $\mathrm{S}$, the $100 \%$ releases of $\mathrm{S}$ and $\mathrm{N}$ (Figure 6) are consistent with full mineralization loss via steps D through $\mathrm{H}$ (all of the S and $25 \%$ of the $\mathrm{N}$ ) and that step I occurred (the other $75 \%$ of the $\mathrm{N}$ ). This reinforces that step $\mathrm{H}$ occurred, even though the TOC results (Figure 2) suggest that step J did not occur. 
In summary, the SD biodegradation pathway, based on a diverse set of the experimental results, explains that the mineralization of ABS (via An) provided internal electron carriers that accelerated the initial mono-oxygenation reactions of SD biodegradation. The faster initial transformation of SD in the P\&B experiments (Fig. 1, 2, and 5), as well as with addition of ABS and An (Fig. 5), the 60\% mineralization (Fig. 2), and the parallel stoichiometric release of S and $\mathrm{N}$ (Fig. 6) support that the ABS and An produced by intimately coupled photolysis accelerated initial mono-oxygenation reactions via the production of intracellular electron carriers at Step H.

\section{Conclusions}

Our experimental results demonstrate that SD biodegradation and mineralization were accelerated by means of intimately coupled UV photolysis. Photolysis of SD generated intermediates ( $\mathrm{An}$ and $\mathrm{ABS}$ ) whose biodegradation generated electron equivalents $(\mathrm{H})$ that stimulated initial SD mono-oxygenation reactions.

\section{Acknowledgements}

The authors acknowledge the financial support by the National Natural Science Foundation of China (50978164), Key project of basic research in Shanghai (11JC1409100), the Special Foundation of Chinese Colleges and Universities Doctoral Discipline (20113127110002), Special Fund of State Key Joint Laboratory of Environment Simulation and Pollution Control (13K09ESPCT), Open research funds from Zhejiang Provincial Key Laboratory of Water Science and Technology, Program of Shanghai Normal University (DZL123 and SK201336), and the 
United States National Science Foundation (0651794), National High Technology Research and Development Program 863(2012AA06A304). 


\section{REFERENCES}

Baran W, Adamek E, Sobczak A, Makowski A (2009a) Photocatalytic degradation of sulfa drugs with $\mathrm{TiO}_{2}, \mathrm{Fe}$ salts and $\mathrm{TiO}_{2} / \mathrm{FeCl}_{3}$ in aquatic environment-kinetics and degradation pathway, Appl. Catal. B Environ. 90(3-4): 516-525.

Baran W, Adamek, E, Sobczak A, Socacka J (2009b) The comparison of photocatalytic activity of Fe-salts, $\mathrm{TiO}_{2}$ and $\mathrm{TiO}_{2} / \mathrm{FeCl}_{3}$ during the sulfanilamide degradation process, Catal. Commun. 10(6): 811-814.

Dahlen E P, Rittmann B E (2000) Analysis of oxygenation reactions in a multi-substrate system - a new approach for estimating substrate-specific true yields. Biotechnol. Bioeng. 70(6):685-92.

García G M J, Díaz-Cruz M S, Barceló D (2012) Removal of sulfonamide antibiotics upon conventional activated sludge and advanced membrane bioreactor treatment. Anal. Bioanal. Chem. 404(5):1505-1515.

Kim I, Tanaka H (2009) Photodegradation characteristics of PPCPs in water with UV treatment. Environment International 35(5):793-802.

Lafaille F, Solassol I, Enjalbal C, Bertrand B, Doulain P E, Vappiani J, Bonnet P A, Deleuze-Masquéfa C, Bressolle F M (2014) Structural characterization of in vitro metabolites of the new anticancer agent EAPB0503 by liquid chromatography-tandem mass spectrometry. J. Pharmaceutical and Biomedical Analysis, 88: 429-440

Li G, Park S, Rittmann B E (2012) Degradation of reactive dyes in a photocatalytic circulating-bed biofilm reactor. Biotechnol. Bioeng. 109(4): 884-893

Li Y, Wang F, Zhou G, Ni Y (2003) Aniline degradation by electrocatalytic oxidation. Chemosphere, 
53(10): 1229-1234

Liu J, Wong M (2013) Pharmaceuticals and personal care products (PPCPs): A review on environmental contamination in China, Environment International, 59: 208-224.

Marsolek M D, Torres C I, Hausner M, Rittmann B E (2008) Intimate coupling of photocatalysis and biodegradation in a photocatalytic circulating-bed biofilm reactor. Biotechnol. Bioeng. 101(1): 83-92

Mohajerani M, Mehrvar M, Ein-Mozaffari F (2012) Using an external-loop airlift sonophotoreactor to enhance the biodegradability of aqueous sulfadiazine solution. Separation and Purification Technology, 90:173 - 181.

Neafsey K, Zeng X, Lemley A T (2009) Degradation of sulfonamides in aqueous solution by membrane anodic Fenton treatment. J. Agricultural and Food Chemistry, 58(2): 1068-1076.

Periša M, Babić S, Škorić I, Frömel T, Knepper P T. (2013) Photodegradation of sulfonamides and their $\mathrm{N}$ 4-acetylated metabolites in water by simulated sunlight irradiation: kinetics and identification of photoproducts. Environmental Science and Pollution Research 20(12): 8934-8946

Sukul P, Lamshöft M, Zühlke S, Spiteller M (2008) Photolysis of ${ }^{14}$ C-sulfadiazine in water and manure. Chemosphere 71 (4): 717-725

Takeo M, Fujii T, Takenaka K, Maeda Y (1998) Cloning and sequencing of a gene cluster for the Meta-cleavage pathway of aniline degradation in Acinetobacter sp. strain YAA. J Fermentation and Bioeng. 85(5): 514-517

von Stosch M, Oliveria R, Peres J (2012) Hybrid modeling framework for process analytical 
technology: Application to Bordetella pertussis cultures. Biotechnol. Progr. 28(1): 284-291.

Wan M, Wang R, Xia J (2012) Physiological evaluation of a new chlorella sorokiniana isolate for its biomass production and lipid accumulation in photoautotrophic and heterotrophic cultures. Biotechnol. Bioeng., 109(8): 1958-1964.

Wang Y, Gao H, Shi Z (2002) HPLC Analysis of Impurity in P-amino benzene sulfonic acid. J. Hebei University (Natural Science Edition), 22(4):363-365 (In Chinese).

Wang Y, Liang J B, Liao X, Wang L, Loh T, Da J, Ho Y (2010) Photodegradation of sulfadiazine by goethite-oxalate suspension under UV Light irradiation. Ind. Eng. Chem. Res., 49(8): $3527-3532$.

Yan N, Xia S, Xu L, Zhu J, Zhang Y, Rittmann B E (2012) Internal loop photobiodegradation reactor (ILPBR) for accelerated degradation of sulfamethoxazole (SMX), Applied Microbio. and Biotechnol., 94(2):527-535

Yu H, Kim B J, Rittmann B E (2001) The role of intermediates and oxygen in biodegradation of benzene, toluene, and p-xylene by Pseudomonas putida F1. Biodegradation, 12(6): 455-463.

Zhao L, Dong Y, Wang H (2010) Residues of veterinary antibiotics in manures from feedlot livestock in eight provinces of China, Science of The Total Environment 408(5): 1069-1075.

Žegura B, Heath E, Černoša A, Filipič M (2009) Combination of in vitro bioassays for the determination of cytotoxic and genotoxic potential of wastewater, surface water and drinking water samples. Chemosphere, 75(11): 1453-1460 
Zhang Y, Chang L, Yan N, Tang Y, Liu R, Rittmann E B (2014) UV photolysis for accelerating pyridine biodegradation. Envir. Sci, \& Technol., 48(1): 649-655

Zhang Y, Sun X, Chen L, Rittmann B E (2012a) Integrated photocatalytic-biological reactor for accelerated 2,4,6-trichlorophenol degradation and mineralization, Biodegradation, 23(1): 189-198

Zhang Y, Pu X, Fang M, Zhu J, Chen L, Rittmann E B (2012b) 2,4,6-trichlorophenol (TCP) photo biodegradation and its effect on community structure, Biodegradation, 23(4): 575-583

Zhou N, Xue G, Bu D, Liu Y (2011) Catalytic ozonation of trace sulfadiazine in water by ZnOOH. China Environment Science, 31(2): 233-238 


\section{Table and Figure Captions:}

\section{Table 1.}

Substrates prepared with different component concentration $(\mathrm{mg} / \mathrm{L})$ for biodegradation (B) experiments.

Table 2. Concentrations (mg/L) contributed by $20-\mathrm{mg} / \mathrm{L}(0.076 \mathrm{mM}) \mathrm{SD}$ and its photolysis products.

Figure 1. SD removal for $\mathrm{P}, \mathrm{B}, \mathrm{P} \& \mathrm{~B}$, and control experiment in the ILPBR. The error bars for protocols $\mathrm{P}, \mathrm{B}$ and $\mathrm{P} \& \mathrm{~B}$ came from the average values of the 2 experimental results.

Figure 2. TOC removal percentages for the $\mathrm{B}$ and $\mathrm{P} \& \mathrm{~B}$ experiments at the end of 4 hours. The $\mathrm{P}$ experiment had no TOC removal and is not shown.

Figure 3. Formation of aniline (An), 2-aminopyrimidine (2-AP), p-aminobenzenesulfonic acid (ABS), sulfate, and ammonia during SD photolysis. TOC removal was negligible and is not shown. 
Figure 4. Proposed SD-photolysis pathway with the number of electron equivalents $\left(\mathrm{e}^{-}\right)$in $\mathrm{C}$ shown for each compound. Balanced reactions for each step are as follows, where $\mathrm{H}$ stands for one electron equivalent, or $\mathrm{H}^{+}+\mathrm{e}^{-}$:

Reaction A: $\quad \mathrm{C}_{10} \mathrm{H}_{10} \mathrm{~N}_{4} \mathrm{O}_{2} \mathrm{~S}+\mathrm{H}_{2} \mathrm{O}=\mathrm{C}_{6} \mathrm{H}_{7} \mathrm{NO}_{3} \mathrm{~S}+\mathrm{C}_{4} \mathrm{H}_{5} \mathrm{~N}_{3}$

Reaction B: $\quad \mathrm{C}_{6} \mathrm{H}_{7} \mathrm{NO}_{3} \mathrm{~S}+\mathrm{H}_{2} \mathrm{O}=\mathrm{C}_{6} \mathrm{H}_{7} \mathrm{~N}+\mathrm{SO}_{4}^{-}+2 \mathrm{H}^{+}$

Reaction $\mathrm{C}: \quad \mathrm{C}_{6} \mathrm{H}_{7} \mathrm{~N}+5 \mathrm{H}_{2} \mathrm{O}=\mathrm{C}_{6} \mathrm{H}_{6} \mathrm{O}_{5}+\mathrm{NH}_{3}+8 \mathrm{H}$

Reaction D: $\quad \mathrm{C}_{4} \mathrm{H}_{5} \mathrm{~N}_{3}+6 \mathrm{H}_{2} \mathrm{O}=4 \mathrm{CH}_{2} \mathrm{O}_{2}+3 \mathrm{NH}_{3}+4 \mathrm{H}$

Figure 5. The effect of adding the different photolysis products on SD biodegradation rates. The regression lines are for zero-order kinetics and for data after 10 minutes.

Figure 6. $\quad \mathrm{N}$ and $\mathrm{S}$ released during $\mathrm{SD}$ biodegradation in $\mathrm{B}$ and $\mathrm{P} \& \mathrm{~B}$ experiments with a starting SD concentration of $10 \mathrm{mg} / \mathrm{L}$. $\mathrm{N} 1$ and $\mathrm{S} 1$ are $\mathrm{N}$ and $\mathrm{S}$ releases that correspond to $100 \%$ mineralization of SD. $\mathrm{N} 2$ and $\mathrm{S} 2$ are the measured $\mathrm{NH}_{3}{ }^{+}-\mathrm{N}$ and $\mathrm{SO}_{4}{ }^{2-}-\mathrm{S}$ concentrations during the experiments.

Figure 7. Proposed SD photo-biodegradation pathway. Each organic intermediate is identified by it name, molecular formula, and numbers of electron $\left(\mathrm{e}^{-}\right)$and $\mathrm{C}$ equivalents in its organic carbon. 
Table 1. Substrates prepared with different component concentration $(\mathrm{mg} / \mathrm{L})$ for biodegradation (B) experiments

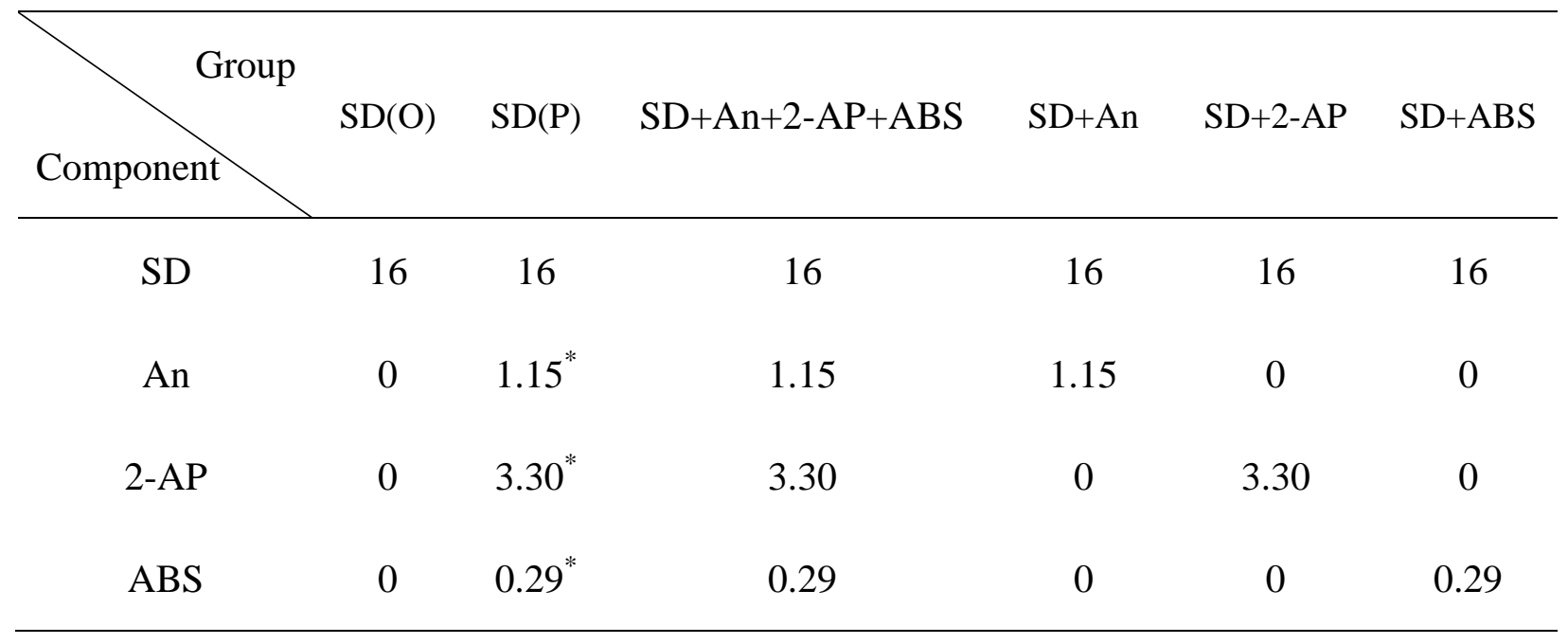

* Produced from UV photolysis 
Table 2. Concentrations $(\mathrm{mg} / \mathrm{L})$ contributed by $20-\mathrm{mg} / \mathrm{L}(0.076 \mathrm{mM}) \mathrm{SD}$ and its photolysis products.

\begin{tabular}{|c|c|c|c|c|c|c|}
\hline Compound & $\begin{array}{c}\text { Molecular } \\
\text { weight }\end{array}$ & $\begin{array}{c}\text { Compound } \\
\mathrm{mg} / \mathrm{L}\end{array}$ & $\begin{array}{c}\text { Molarity } \\
\mathrm{mM}\end{array}$ & $\begin{array}{c}\mathrm{N} \\
\mathrm{mgN} / \mathrm{L}\end{array}$ & $\begin{array}{c}\mathrm{S} \\
\mathrm{mgS} / \mathrm{L}\end{array}$ & $\begin{array}{c}\text { TOC } \\
\mathrm{mgC} / \mathrm{L}\end{array}$ \\
\hline $\begin{array}{l}\text { Initial Sulfadiazine (SD) } \\
\left(\mathrm{C}_{10} \mathrm{H}_{10} \mathrm{~N}_{4} \mathrm{O}_{2} \mathrm{~S}\right)^{\mathrm{a}}\end{array}$ & 250 & 18.91 & 0.076 & 4.230 & 2.417 & 9.064 \\
\hline $\begin{array}{l}p \text {-aminobenzenesulfonic } \\
\text { acid }\left(\mathrm{C}_{6} \mathrm{H}_{7} \mathrm{NO}_{3} \mathrm{~S}\right)\end{array}$ & 173 & 1.386 & 0.008 & 0.112 & 0.256 & 0.576 \\
\hline $\begin{array}{l}\text { 2-aminopyrimidine } \\
\left(\mathrm{C}_{4} \mathrm{H}_{5} \mathrm{~N}_{3}\right)\end{array}$ & 95 & 6.513 & 0.068 & 2.876 & $\mathbf{0}$ & 3.287 \\
\hline Aniline $\left(\mathrm{C}_{6} \mathrm{H}_{7} \mathbf{N}\right)$ & 93 & 6.169 & 0.066 & 0.927 & $\mathbf{0}$ & 4.769 \\
\hline Sulfate $\left(\mathrm{SO}_{4}{ }^{2-}\right)$ & 96 & 6.423 & 0.066 & $\mathbf{0}$ & 2.141 & $\mathbf{0}$ \\
\hline $\begin{array}{l}\text { 2-Hydroxyhexa-2,4-diendioic } \\
\text { acid }\left(\mathrm{C}_{6} \mathrm{H}_{6} \mathrm{O}_{5}\right)^{\mathbf{b}}\end{array}$ & 158 & 0.790 & 0.005 & 0 & 0 & 0.240 \\
\hline $\operatorname{Ammonia}\left(\mathrm{NH}_{3}\right)^{\mathrm{c}}$ & 17 & 0.085 & 0.005 & 0.070 & $\mathbf{0}$ & $\mathbf{0}$ \\
\hline Formic acid $\left(\mathrm{CH}_{2} \mathrm{O}_{2}\right)$ & 46 & 0.920 & 0.020 & 0 & 0 & 0.240 \\
\hline $\operatorname{Ammonia}\left(\mathrm{NH}_{3}\right)^{\mathrm{d}}$ & 17 & 0.255 & 0.015 & 0.210 & $\mathbf{0}$ & $\mathbf{0}$ \\
\hline Element sums for products ${ }^{\mathrm{e}}$ & & & & 4.195 & 2.397 & 9.112 \\
\hline
\end{tabular}

${ }^{a}$ Boldface indicates a directly measured concentration.

${ }^{\text {b }}$ Italics indicate that the concentration was computed from the N, S, and C mass balances.

c This $\mathrm{NH}_{3}$ comes from reaction $\mathrm{C}$.

${ }^{\mathbf{d}}$ This $\mathrm{NH}_{3}$ comes from reaction $\mathrm{D}$.

e This row is sum of all SD photolysis products. 
Figure 1

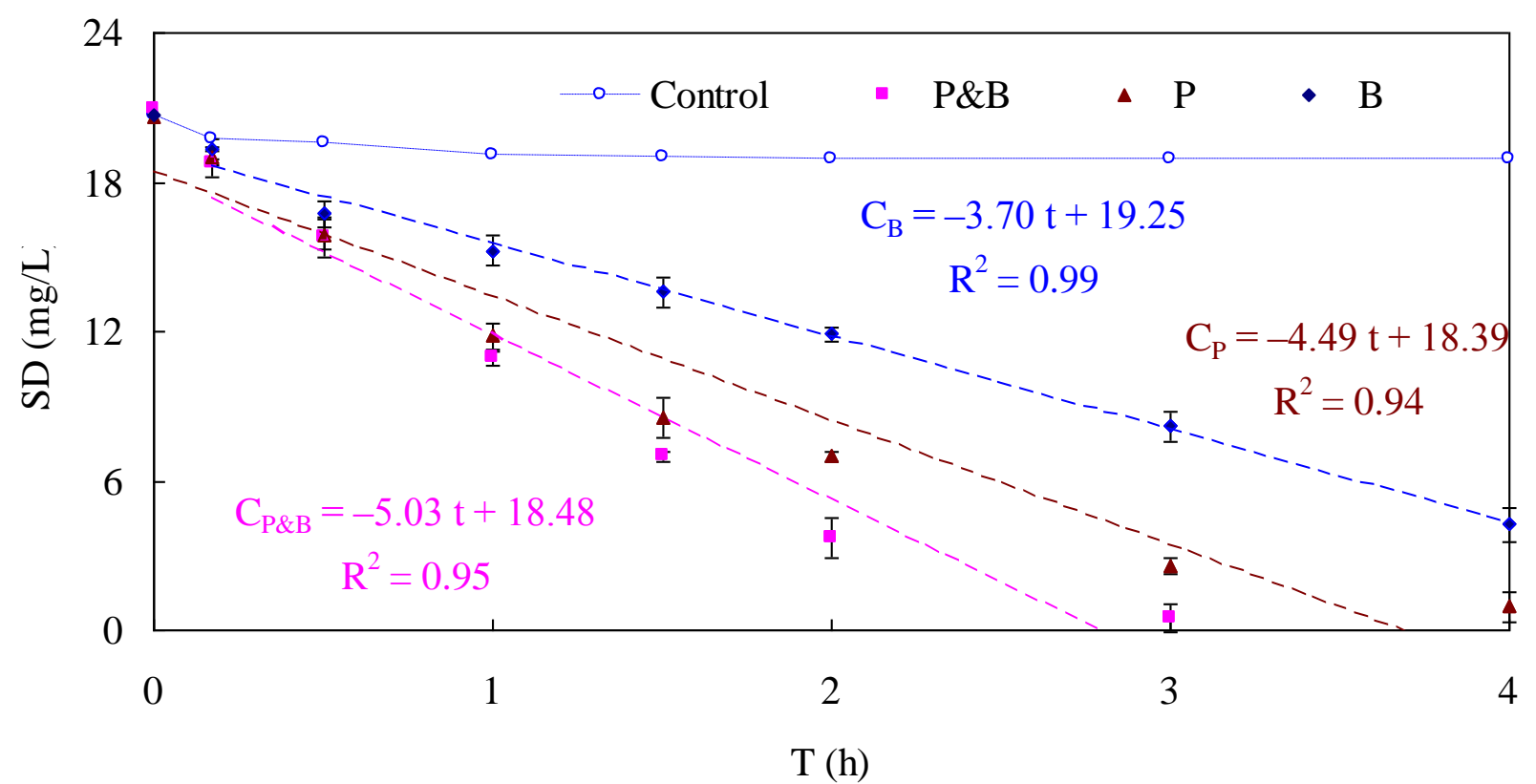

Figure 1. SD removal for P, B, P\&B, and control experiment in the ILPBR. The error bars for protocols $\mathrm{P}, \mathrm{B}$ and $\mathrm{P} \& \mathrm{~B}$ came from the average values of the 2 experimental results. 
Figure 2

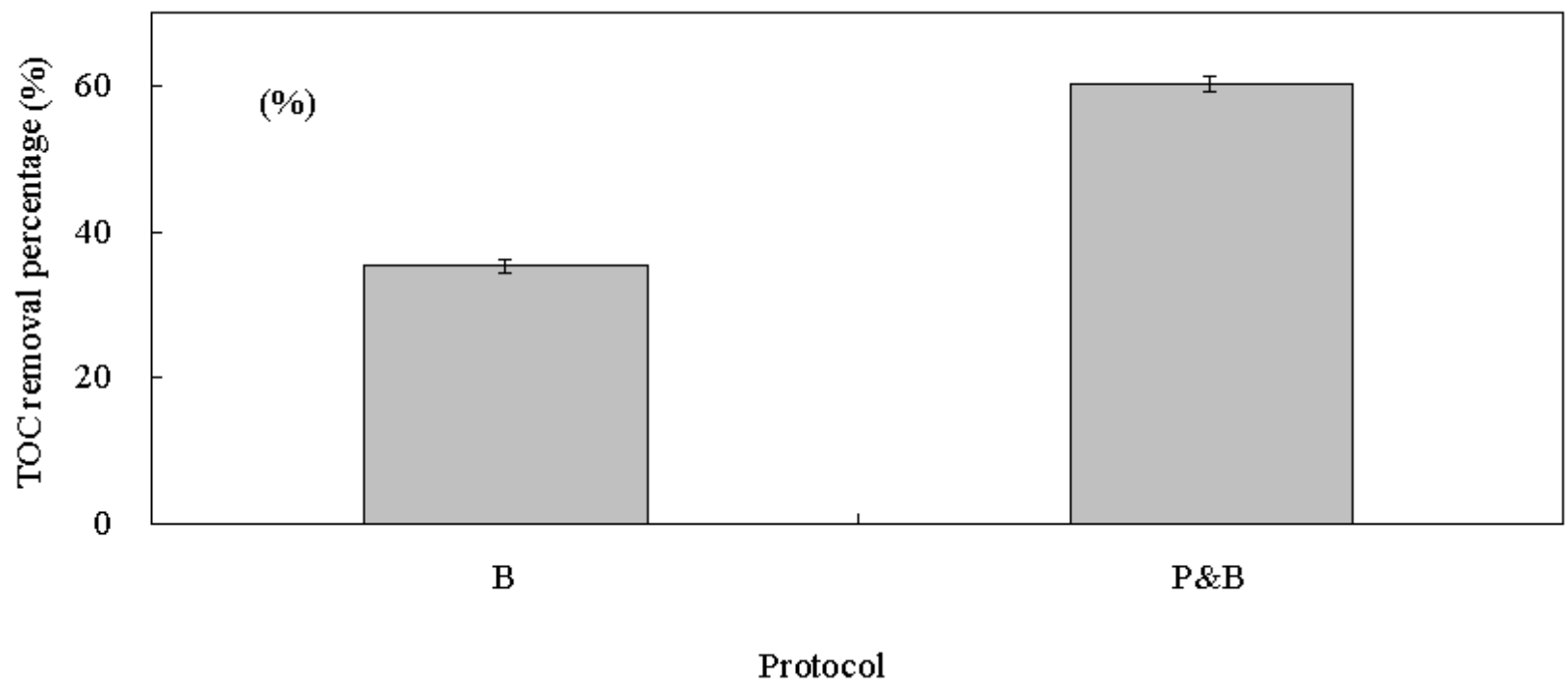

Figure 2. TOC removal percentages for the B and P\&B experiments at the end of 4 hours. The $\mathrm{P}$ experiment had no TOC removal and is not shown. 
Figure 3

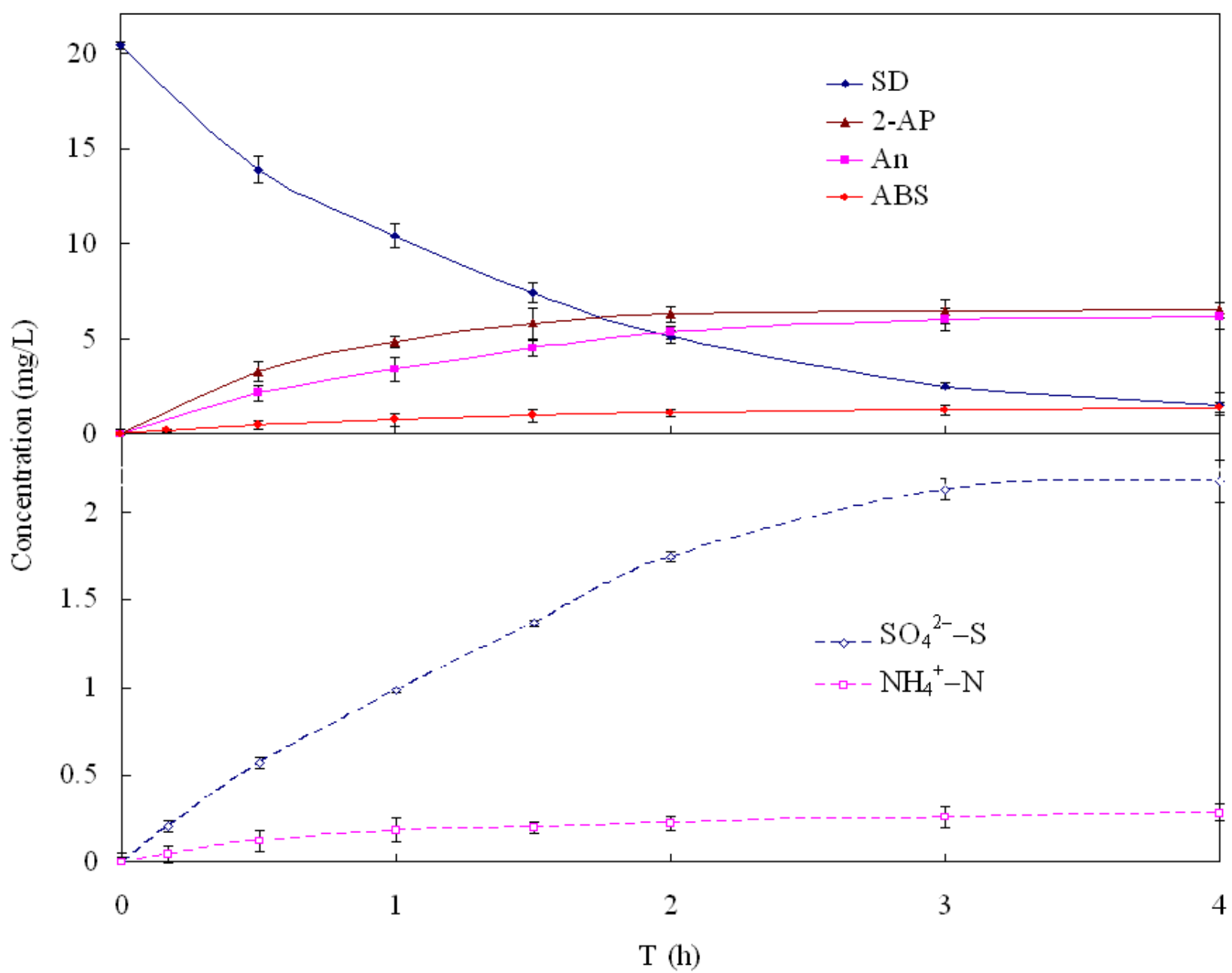

Figure 3. Formation of aniline (An), 2-aminopyrimidine (2-AP), p-aminobenzenesulfonic acid (ABS), sulfate, and ammonia during SD photolysis. TOC removal was negligible and is not shown. 
Figure 4

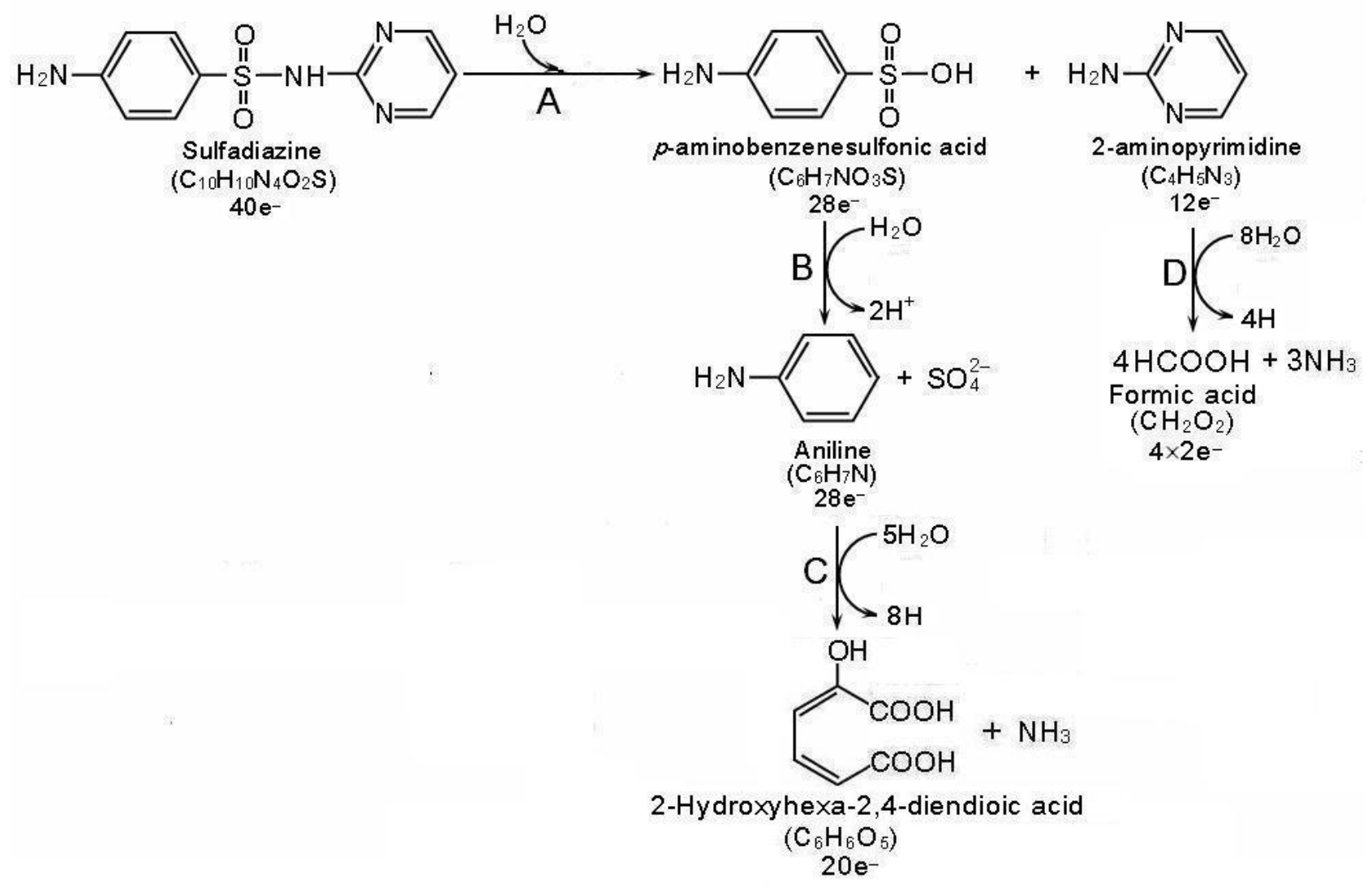

Figure 4 Proposed SD-photolysis pathway with the number of electron equivalents ( $\mathrm{e}^{-}$) in $\mathrm{C}$ shown

for each compound. Balanced reactions for each step are as follows, where $\mathrm{H}$ stands for one electron equivalent, or $\mathrm{H}^{+}+\mathrm{e}^{-}$:

Reaction A: $\quad \mathrm{C}_{10} \mathrm{H}_{10} \mathrm{~N}_{4} \mathrm{O}_{2} \mathrm{~S}+\mathrm{H}_{2} \mathrm{O}=\mathrm{C}_{6} \mathrm{H}_{7} \mathrm{NO}_{3} \mathrm{~S}+\mathrm{C}_{4} \mathrm{H}_{5} \mathrm{~N}_{3}$

Reaction B: $\quad \mathrm{C}_{6} \mathrm{H}_{7} \mathrm{NO}_{3} \mathrm{~S}+\mathrm{H}_{2} \mathrm{O}=\mathrm{C}_{6} \mathrm{H}_{7} \mathrm{~N}+\mathrm{SO}_{4}{ }^{-}+2 \mathrm{H}^{+}$

Reaction $\mathrm{C}: \quad \mathrm{C}_{6} \mathrm{H}_{7} \mathrm{~N}+5 \mathrm{H}_{2} \mathrm{O}=\mathrm{C}_{6} \mathrm{H}_{6} \mathrm{O}_{5}+\mathrm{NH}_{3}+8 \mathrm{H}$

Reaction D: $\quad \mathrm{C}_{4} \mathrm{H}_{5} \mathrm{~N}_{3}+6 \mathrm{H}_{2} \mathrm{O}=4 \mathrm{CH}_{2} \mathrm{O}_{2}+3 \mathrm{NH}_{3}+4 \mathrm{H}$ 
Figure 5

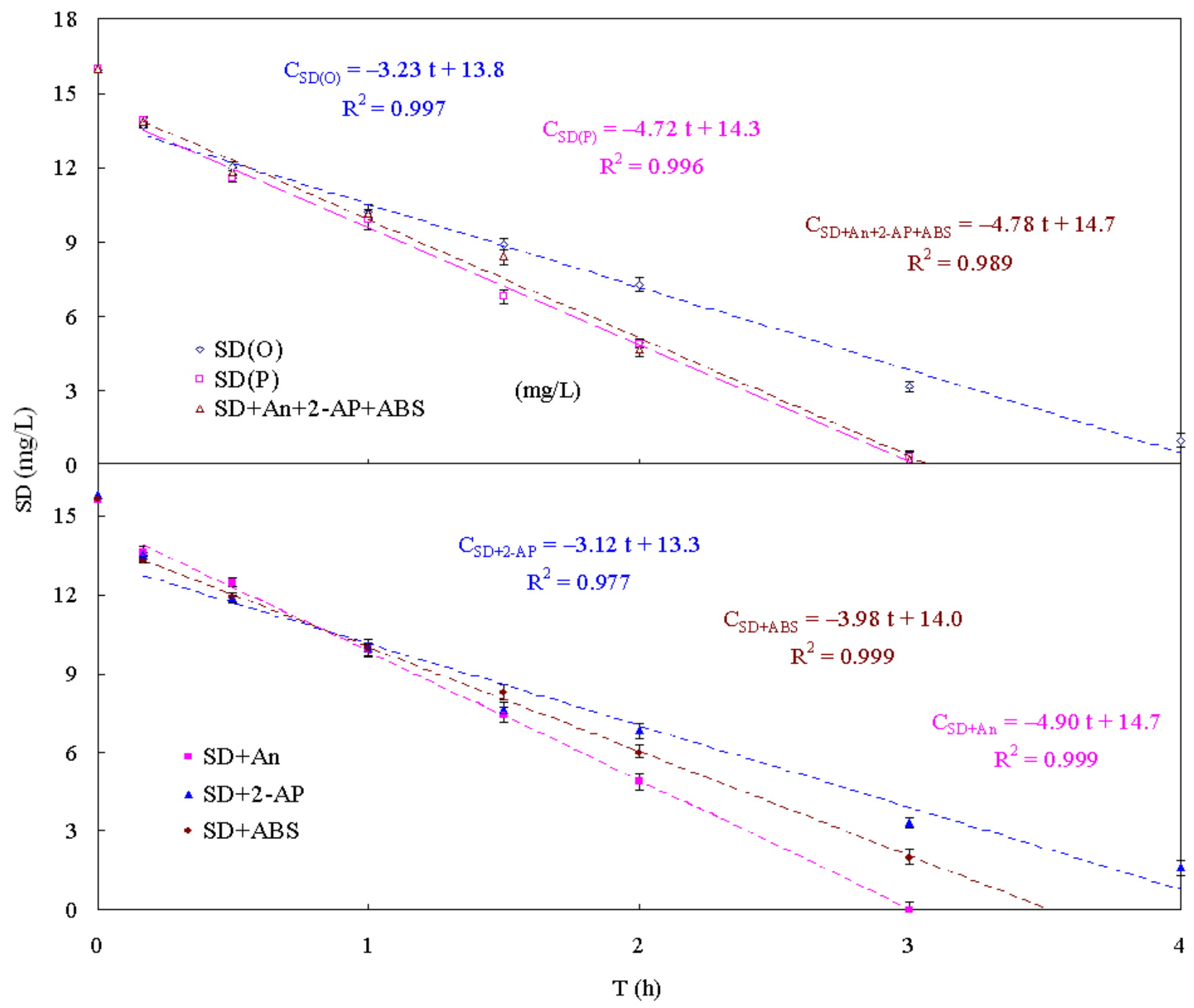

Figure 5. The effect of adding the different photolysis products on SD biodegradation rates. The regression lines are for zero-order kinetics and for data after 10 minutes. 
Figure 6

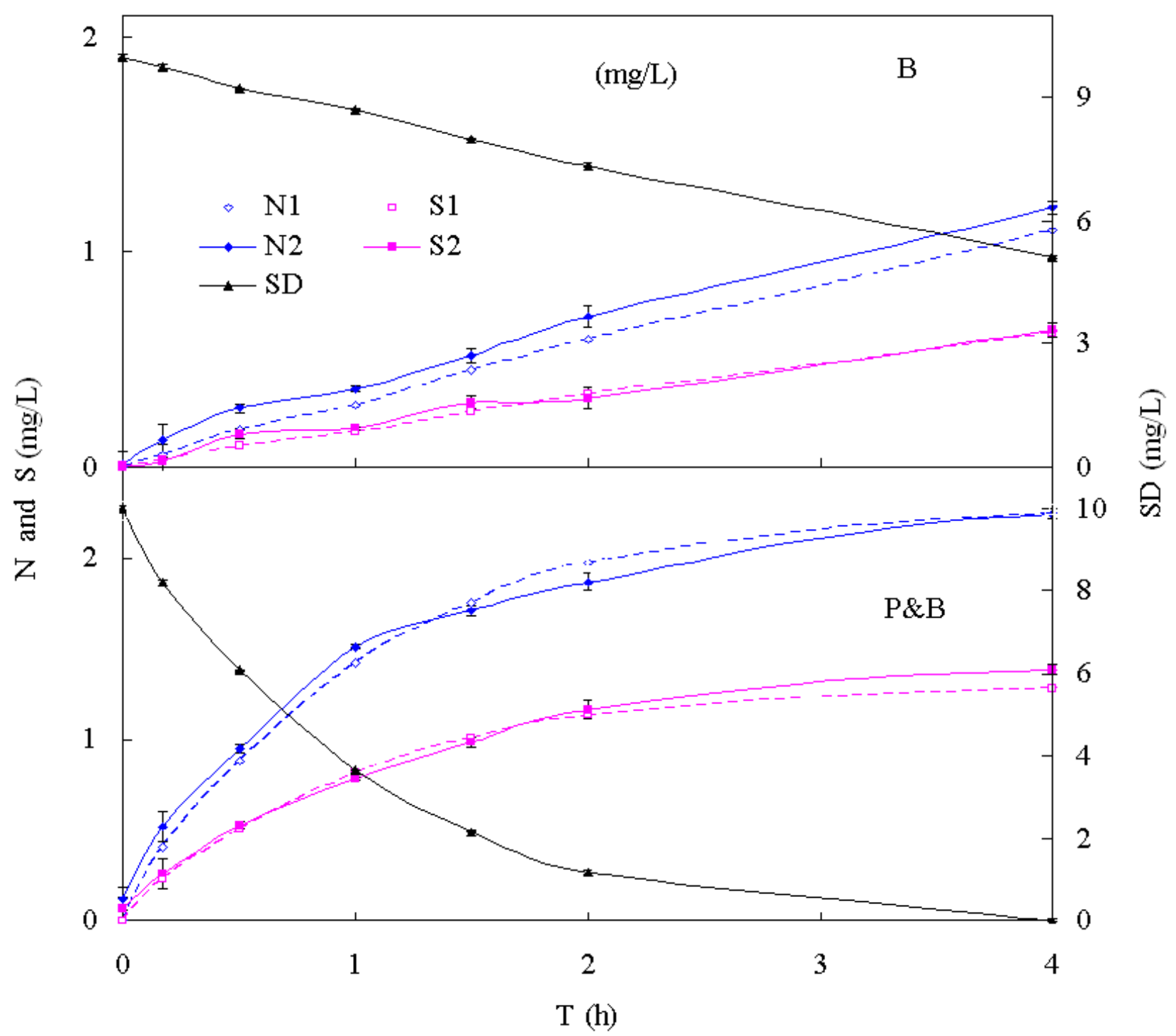

Figure 6. $\mathrm{N}$ and $\mathrm{S}$ released during $\mathrm{SD}$ biodegradation in $\mathrm{B}$ and $\mathrm{P} \& \mathrm{~B}$ experiments with a starting SD concentration of $10 \mathrm{mg} / \mathrm{L}$. $\quad \mathrm{N} 1$ and $\mathrm{S} 1$ are $\mathrm{N}$ and $\mathrm{S}$ releases that correspond to $100 \%$ mineralization of SD. $\mathrm{N} 2$ and $\mathrm{S} 2$ are the measured $\mathrm{NH}_{3}{ }^{+}-\mathrm{N}$ and $\mathrm{SO}_{4}{ }^{2-}-\mathrm{S}$ concentrations during the experiments. 
Figure 7

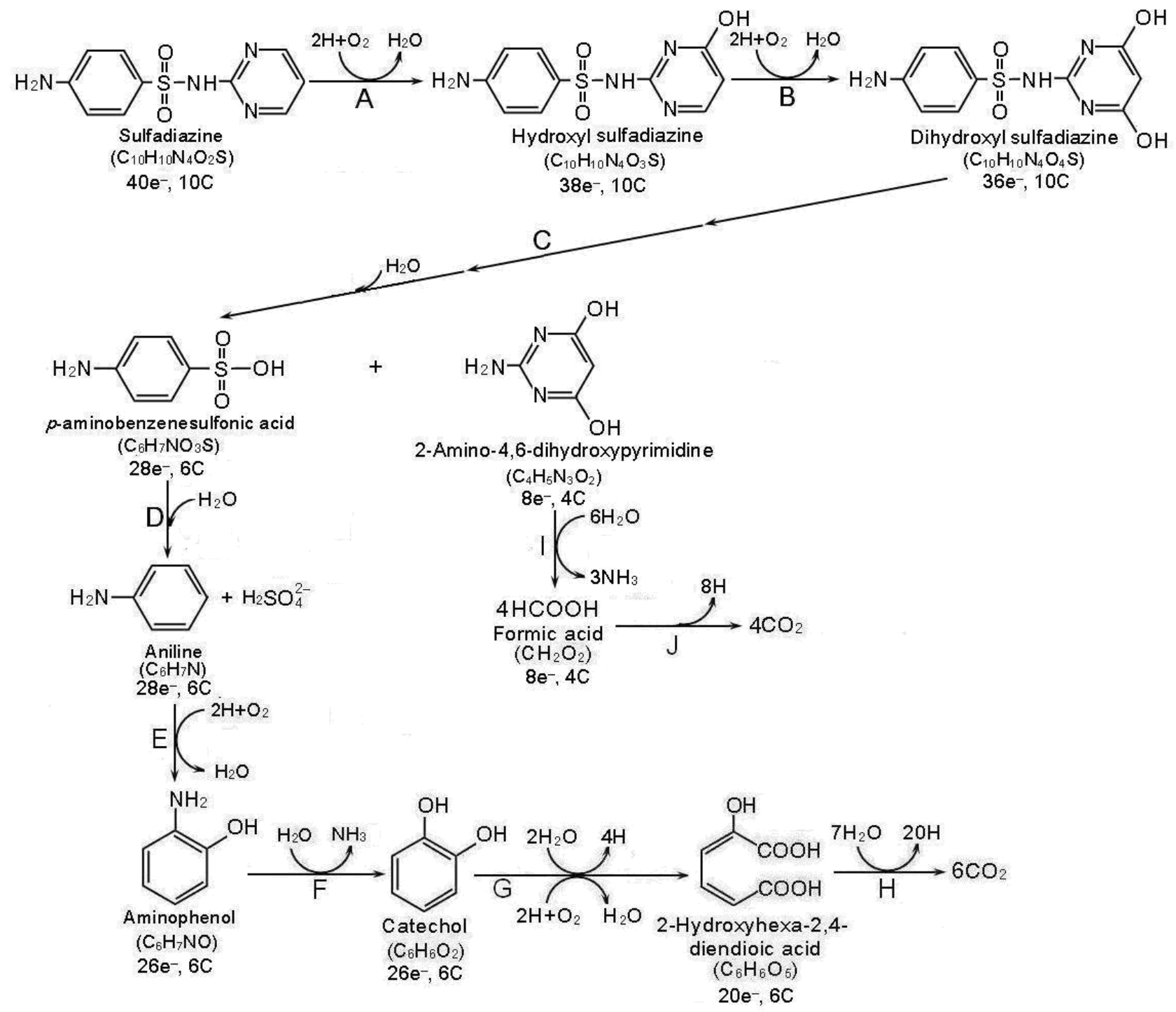

Figure 7. Proposed SD photo-biodegradation pathway. Each organic intermediate is identified by it name, molecular formula, and numbers of electron $\left(\mathrm{e}^{-}\right)$and $\mathrm{C}$ equivalents in its organic carbon. 


\section{Cover Letter}

May 15, 2014

\section{Dear Editor,}

Enclosed please find our manuscript entitled, "How UV photolysis accelerates the biodegradation and mineralization of sulfadiazine (SD)" to be considered for publication in

\section{Biodegradation.}

This research explores the mechanism by which UV photolysis accelerates sulfadiazine (SD) biodegradation. We employed an internal loop photobiodegradation reactor (ILPBR) to realize intimately coupled UV photolysis with biodegradation following three protocols: biodegradation alone $(\mathrm{B})$, photolysis alone $(\mathrm{P})$, and photobiodegradation $(\mathrm{P} \& \mathrm{~B})$. The experimental results showed that $\mathrm{P} \& \mathrm{~B}$ was superior to $\mathrm{B}$ and $\mathrm{P}$ in terms of accelerating SD biodegradation and mineralization. We hypothesized that UV photolysis generated biodegradable intermediates whose oxidation accelerated SD biodegradation through the production of intracellular electron carriers needed for initial mono-oxygenation reactions. We evaluated the hypothesis by adding the detected SD photolysis intermediates during biodegradation experiments (no UV photolysis). We found that two of the photolysis intermediates -- $p$-aminobenzenesulfonic acid (ABS) and aniline (An) gave SD removal and mineralization rates similar to intimately coupled photolysis and biodegradation (P\&B). We also used mass-balance analyses of $\mathrm{B}$ and $\mathrm{P} \& \mathrm{~B}$ experiments to develop a biodegradation pathway and demonstrate that $\mathrm{ABS}$ and An were fully mineralized to produce the intracellular electron carriers. Thus, we developed multiple lines of evidence support that the mechanism by which intimately coupled photolysis and biodegradation accelerated SD removal and mineralization was through producing co-substrates whose oxidation produced electron equivalents that stimulated the initial mono-oxygenation reactions for SD biodegradation.

I am looking forward to our next correspondence.

Sincerely,

Yongming Zhang, Ph.D., Professor and Chairman

Department of Environmental Engineering, Shanghai Normal University

100 Guilin Road, Shanghai 200234 P. R. China

Email: zhym@shnu.edu.cn 


\section{Suggested reviewers:}

Seongjun Park: Construction Technology Center, Samsung Construction and Trading, Seoul, Republic of Korea, seongjun93.park@samsung.com

Elizabeth Dahlen: Stanford Linear Accelerator Complex (SLAC), eliz.dahlen@ gmail.com

Michael D. Marsolek: Department of Civil and Environmental Engineering, Seattle University, Seattle, WA 98122, marsolem@ @eattleu.edu

Maria Papadaki: Department of Environmental and Natural Resources Management, University of Ioannina, Greece. m.papadaki@leeds.ac.uk or mpapadak@cc.uoi.gr

Jian-Jiang Zhong: Shanghai Jiaotong University, jizhong@sjtu.edu.cn 